\title{
LOCAL STABILITY OF WEB OF TAPERED BEAM SUBJECTED TO PURE BENDING
}

\author{
Vaidotas Šapalas \\ Vilnius Gediminas Technical University, Sauletekio al. 11, LT-10223 Vilnius, Lithuania \\ E-mail: vaidotas.sapalas@vgtu.lt \\ Received 06 Oct. 2009; accepted 10 Nov. 2009
}

\begin{abstract}
This paper deals with a theoretical and a numerical analysis of local stability of web of tapered beams subjected to a pure bending moment. A standard FEM code COSMOS/M has been used for a numerical estimation of a critical load multiplier. It has been assumed that the critical stress of the web of tapered beam could be calculated in an analogous way as for uniform member just with an additional correction factor $\alpha_{b . w}$. A large number of simulations carried out within a wide range of the ratios of second moments of area allowed to determine the proper values of that factor. In the paper there was investigated the influence of steel grade, relative slenderness and beam's ends cross-section moments of inertia ratio to the local stability of web of the tapered beam subjected to pure bending.
\end{abstract}

Keywords: local stability of web, tapered beam subjected to pure bending, finite element method, critical stress of the web, warping.

\section{Introduction}

During the last years, light steel structures have been extensively used as being the most effective in practical application. The main advantages of such kind of structures are the effective usage of materials and quick erection as well as their good exploitation characteristics. Over the past two decades, solution of the buildings with tapered frames, manufactured from high-tensile steel, have become a standard. The use of automatic welding techniques minimizes the cost of such tapered members. Their contours are quite close to the bending moment diagram form, so the bearing capacity of cross sections is effectively utilized. With this type of frames the web depth-to-thickness ratio can exceed 200. There is no need in many additional stiffeners in this case.

Analysis of such kind of frames is rather complicated and not widely investigated in the literature. For example, there are no recommendations in Eurocode 3 (2006) how to calculate such structural members. A thinwalled beam subjected to bending moment can loose stability in lateral torsional buckling mode.

Stability of tapered elements was investigated in references Bazeos, Karabalis (2006), Becque, Rasmussen (2009), Raftoyiannis, Ermopoulos (2005), Saffari et al. (2008), Salem et al. (2009), Šapalas et al. (2000, 2002, 2004, 2005). Authors of which proposed to calculate tapered columns as uniform members, using additional factors, so that failure was only due to overall buckling and yielding. This treatment is appropriate for solid section members, and for members whose cross-sections are composed of comparatively thick-plate elements, including many hot-rolled steel sections.

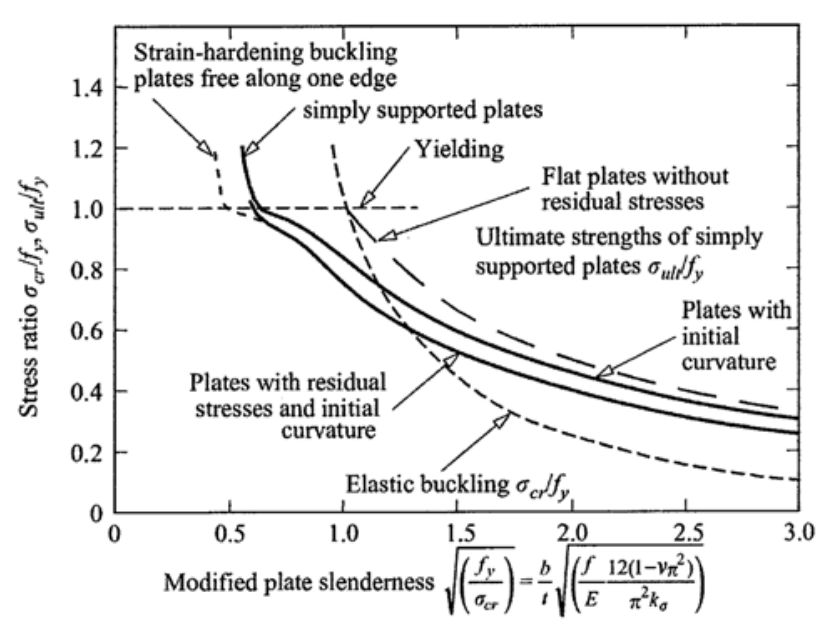

Fig. 1. Ultimate strength of plates

However, in some cases the member cross-section is composed of more slenderplate elements. These slenderplate elements may buckle locally and the member may fail prematurely. A slender-plate element does not fail by elastic buckling, but exhibits significant post-buckling behaviour. Because of this, the plate's resistance to local failure depends not only on its slenderness, but also on its yield strength and residual stresses, as shown in Fig. 1. The resistance of a plate element of intermediate slenderness is also influenced significantly by its geometrical imperfections, while the resistance of a stocky-plate element depends primarily on its yield stress and strainhardening moduli of elasticity, as indicated in Fig. 1.

Some authors investigated local stability of tapered members Moon et al. (2009), Zhang, Tong (2008). 


\section{Stability theory of plate elements}

\subsection{Plate elements in bending}

The thin flat plate of length $L$, width $d$, and thickness $t$ shown in Fig. 2 is simply supported along all four edges. The plate is loaded by bending stress distributions which vary linearly across its width.

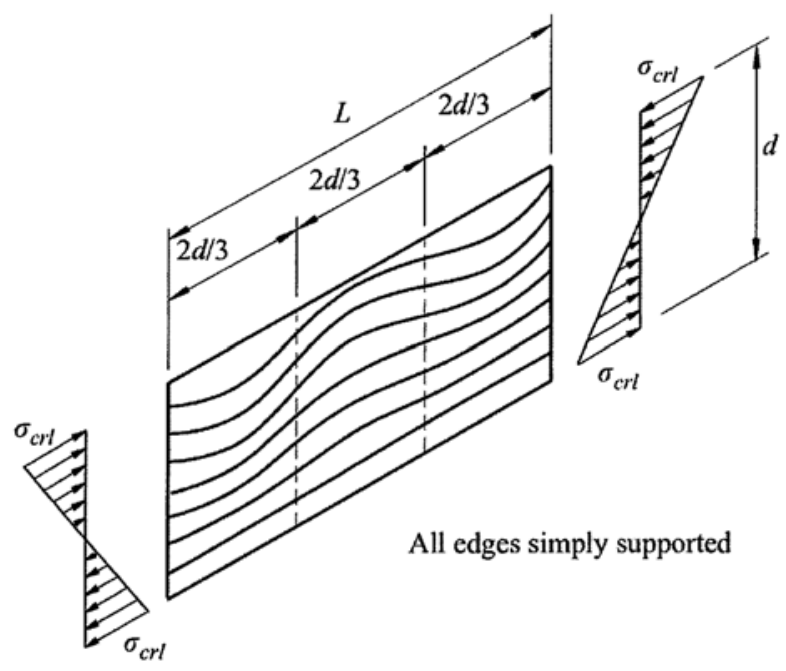

Fig. 2. Buckle patern of a plate in bending

When the maximum stress reaches the elastic buckling value $\sigma_{c r l}$ the plate can buckle out of its original plane as shown in Fig. 2. The elastic buckling stress can be expressed in the form:

$$
\sigma_{c r l}=\frac{\pi^{2} \cdot E}{12 \cdot\left(1-v^{2}\right)} \cdot \frac{k_{\sigma}}{(d / t)^{2}}
$$

$k_{\sigma}$ - buckling coeficient depends on $L / d$ ratio and the number of buckles along the plate.

Local stability of web of the uniform cross-section beam without local stresses $\sigma_{l o c}=0$ according to Lithuanian design code should be checked by formula:

$$
\sqrt{\left(\frac{\sigma_{w, x, E d}}{\sigma_{w, c r, R d}}\right)^{2}} \leq 1
$$

$\sigma_{w, x, E d}$ - elastic buckling stresses calculated using formula:

$$
\sigma_{w, x, E d}=\frac{M_{E d}}{I_{y}} \cdot z,
$$

$\sigma_{w, c r, R d}-$ critical buckling stresses calculated using formula:

$$
\sigma_{w, c r, R d}=\frac{c_{c r} \cdot f_{y, d}}{\bar{\lambda}_{w}^{2}},
$$

$\bar{\lambda}_{w}=h_{w} / t \cdot \sqrt{f_{y, d} / E}$ - relative slenderness of web; $c_{c r}$ - critical buckling factor depending on geometrical characteristics of the cross-section of the beam taken according to the factor $\delta$ :

$$
\delta=\beta \cdot \frac{b_{f}}{h_{w}} \cdot\left(\frac{t_{f}}{t_{w}}\right)^{3}
$$

$\beta=0.8-$ factor for I section beams.

\subsection{Stability of web of tapered beam}

In this paper the beam subjected to pure bending (Fig. 3) was investigated.

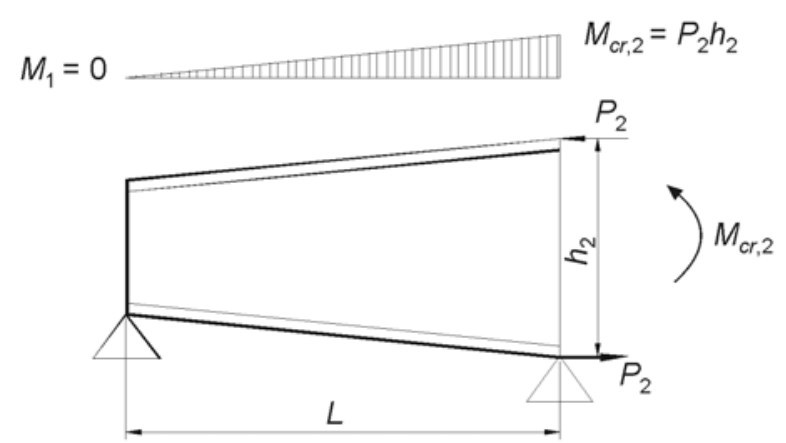

Fig. 3. Tapered beam subjected to pure bending

According to Academician Dinnik (1955) tapered member can be described using beam's ends crosssection moments of inertia ratio (nondimensional):

$$
k=\frac{I_{y 1}}{I_{y 2}} .
$$

Solving the equation (2) the critical bending moment $M_{c r, 2}$ value for an unifom cross-section beam can be obtained. Critical bending moment of tapered beam can be calculated according to the formula:

$$
M_{\text {tap }}=\alpha_{b . w} \cdot M_{c r, 2} \text {. }
$$

In the paper there was investigated the influence of steel grade, relative slenderness and beam's ends crosssection moments of inertia ratio to the local stability of web of the tapered beam subjected to pure bending.

The dimensions of beam were chosen: lengh of beam - $L=5 \mathrm{~m}$; width of flange of the beam $b_{f}=0.2 \mathrm{~m}$; thickness of flange $t_{f}=0.01 \mathrm{~m}$. Beam's bigger end cross-section height $h_{2}=0.5 \mathrm{~m}$.

Beam's ends cross-section moments of inertia ratio vary:

$$
k=0.05 ; 0.2 ; 0.4 ; 0.6 ; 0.8 ; 1.0 .
$$

Beam's ends cross-section moments of inertia ratio varies using difrent beam's smallest cross-section height (Table 1).

Table 1. Beam's smallest cross-section height

\begin{tabular}{ccccccc}
\hline $\mathrm{k}$ & 0.05 & 0.2 & 0.4 & 0.6 & 0.8 & 1.0 \\
$h_{1}$ & 0.0625 & 0.238 & 0.328 & 0.40 & 0.452 & 0.5 \\
$(\mathrm{~m})$ & & & & & & \\
\hline
\end{tabular}

Thickness of the web was taken so that relative slenderness varies from 3.5 to 6.0 (Table 2). 
Table2. Thickness of web

\begin{tabular}{c|c|c|c}
\hline \multirow{2}{*}{$\begin{array}{c}\text { Relative slen- } \\
\text { derness of } \\
\text { web } \bar{\lambda}_{w}\end{array}$} & \multicolumn{3}{|c}{ Thickness of web $t_{w}(\mathrm{~m})$ depending on steel } \\
\cline { 2 - 4 } & $\mathrm{S} 235$ & $\mathrm{~S} 275$ & $\mathrm{~S} 355$ \\
\hline 3.5 & 0.00458 & 0.00497 & 0.00553 \\
\hline 4.0 & 0.004 & 0.00434 & 0.00484 \\
\hline 4.5 & 0.00356 & 0.00386 & 0.0043 \\
\hline 5.0 & 0.00321 & 0.00348 & 0.00387 \\
\hline 5.5 & 0.00292 & 0.00316 & 0.00352 \\
\hline 6.0 & 0.00267 & 0.0029 & 0.00323 \\
\hline
\end{tabular}

According to this data there was calculated critical bending moment $M_{c r, 2}$ (Fig. 4) as for uniform member for various steel classes and relative slenderness of web.

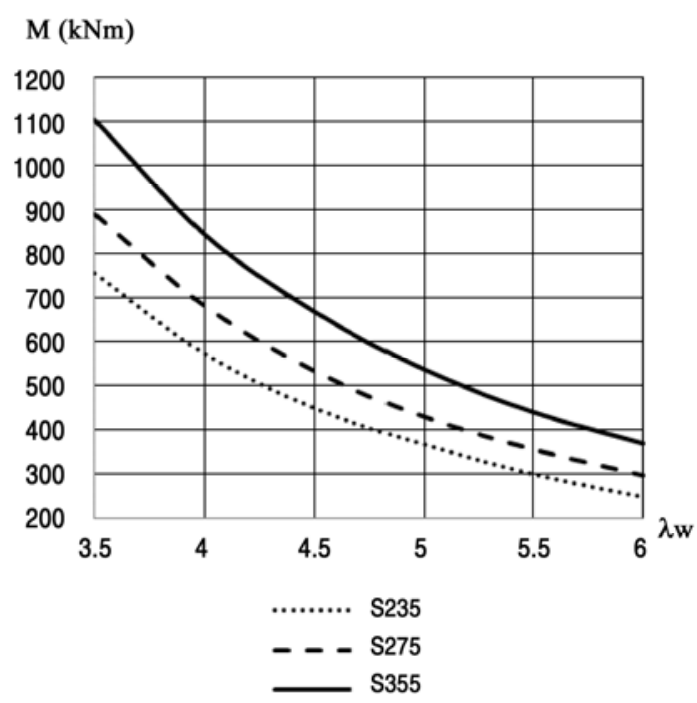

Fig. 4. Critical bending moment depending on relative slenderness of web and steel class

\section{Stability analysis by the finite element method}

\subsection{Concepts of the stability analysis}

The FEM has long been recognised as one of the most effective techniques for analysing common thin-walled structures and their structural members under arbitrary loading and boundary conditions Andrade et al. (2007), Das et al. (2009), Yau (2006), Li (2002), Ozgumus, Kaya (2007), Ronagha et al. (2000), Samofalov et al. (2004), Šešok, Belevičius (2008).

The most general critical condition, at which stability of a structure impends, is obtained considering second variation of the total potential energy. By applying a standard finite element approach, the system of geometrically non-linear equations can be symbolically written in the following form:

$$
\mathbf{A}(\mathbf{F}, \mathbf{u})=\mathbf{0},
$$

A - a differential operator, in the most general case nonlinear in load $\mathbf{F}$ and displacement $\mathbf{u}$. This equation can be presented by incremental form:

$$
\left(\left[\mathbf{K}_{\text {lin }}\right]+\left\lfloor\mathbf{K}_{g}\right\rfloor+\left[\mathbf{K}_{u}\right]\right) \Delta \mathbf{u}=\Delta \mathbf{F},
$$

$\left[\mathbf{K}_{\text {lin }}\right]$ - a linear elastic stiffness matrix, $\left[\mathbf{K}_{g}\right]$ is an geometric stiffness matrix, $\left[\mathbf{K}_{u}\right]$ is an initial displacement stiffness matrix, $\Delta \mathbf{u}$ is a vector of displacement increments and $\Delta \mathbf{F}$ is the increment of the external loading.

In the presented research, the stability problem is limited by linearized formulation of the lateral buckling, when only small strains and finite rotations have to be considered, i.e. $\left[\mathbf{K}_{u}\right]=0$. It is assumed that the load state is described by external load vector $\mathbf{F}$ and a scalar load-intensity factor $\lambda_{c r}$. The second variation of the total potential energy provides a mathematical model of the stability problem expressed as well known in mathematics as eigenvalue problem:

$$
\left(\left[\mathbf{K}_{\text {lin }}\right]+\lambda_{c r}\left\lfloor\mathbf{K}_{g}\right\rfloor\right) \mathbf{r}_{c r}=\mathbf{0},
$$

$\left[\mathbf{K}_{g}\right]$ - a geometric stiffness matrix, while $\lambda_{c r}$ is the stability load factor and $\mathbf{r}_{c r}$ is the vector of buckling mode shapes. The number of given values for the load factor and shape modes depends on the number of the equations, consisted in system (10). The most interesting research in civil engineering is the first value and corresponding shape mode, while other results are more important for theoretical analysis.

For modelling the typical triangle shell element from the code COSMOS/M was applied (Fig. 5). These finite elements are defined by 18 DOF. Each of nodes of such $\mathrm{FE}$ is described by three linear displacements $u_{x}, u_{y}$ and $u_{z}$ and three rotations $\varphi_{x}, \varphi_{y}$ and $\varphi_{z}$.

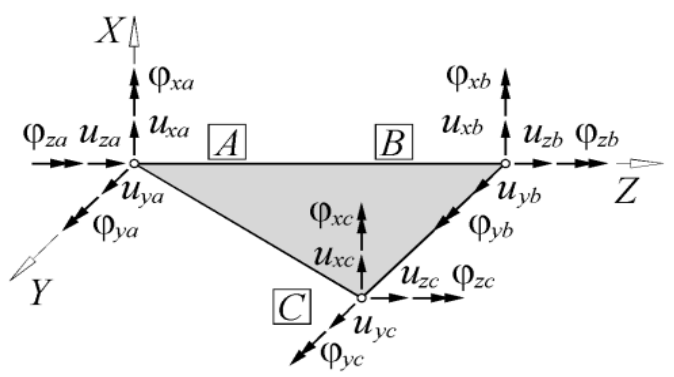

Fig. 5. Shell FE with its DOF

The above-mentioned finite elements have been used for the buckling analysis of beam.

\subsection{Numerical solution of the local stability of web of the tapered beam}

The beam has been modelled by using an assumption, that its cross sections are subjected to bending moments only, end-sections " $A$ " and " $B$ " have been supported in the cross-sectional direction and one of the ends had the axial node, which cannot move in the longitudinal direction. Many of solutions with a wide range of the ratios of crosssectional characteristics have been carried out. At the bigger end the beam has been subjected to the critical bending moment $M_{c r, 2}$ (Fig. 6), given as for an uniform member by using the bigger end geometrical characteristics. 


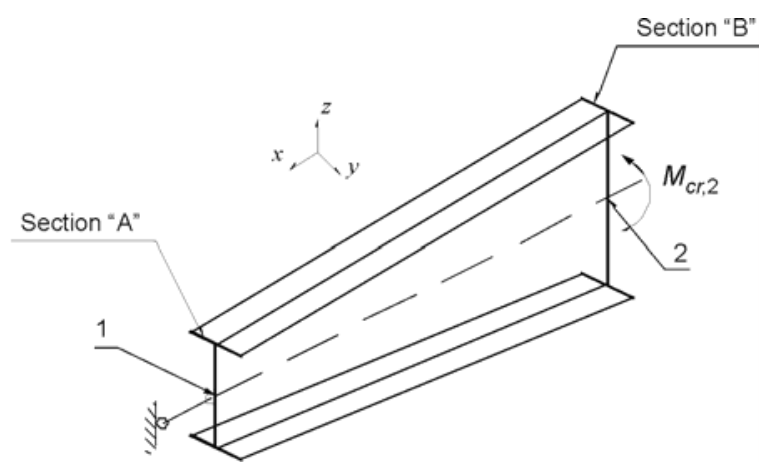

Fig. 6. Geometry and external loading by the bending moment of the tapered beam

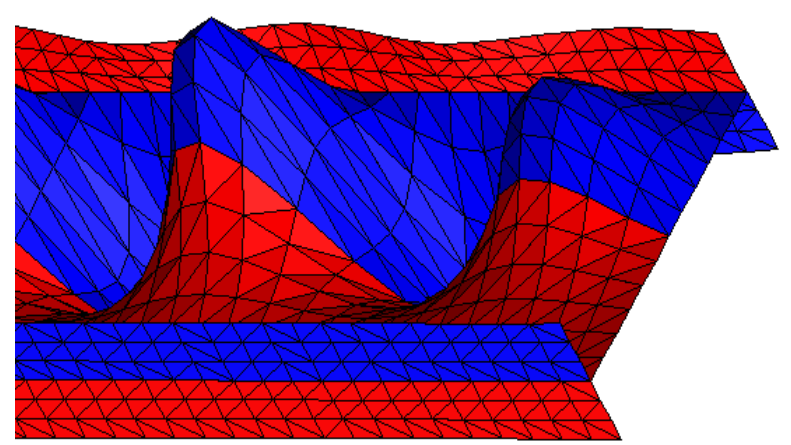

Fig. 7. Local buckling shape mode of the tapered beam, according solution by the FEM code COSMOS/M

There were carried out a large number of simulations within a wide range of variations of the moment of inertia of the beam cross-section. Firstly, the beam has been loaded by bending moment $M_{c r, 2}$, solved as for the uniform member. Secondly, by using an original program COSMOS/M (Fig. 7) the correction factor $\alpha_{b . w}$ has been calculated.

From these simulations many values of the correction factor $\alpha_{b . w}$ for the pin-ended beam subjected to pure bending have been calculated (Fig. 8-17). By using computer simulations there have been determined, that values of correction factor $\alpha_{b . w}$ found for pin-ended beam can also be used for other types of the beam support conditions.

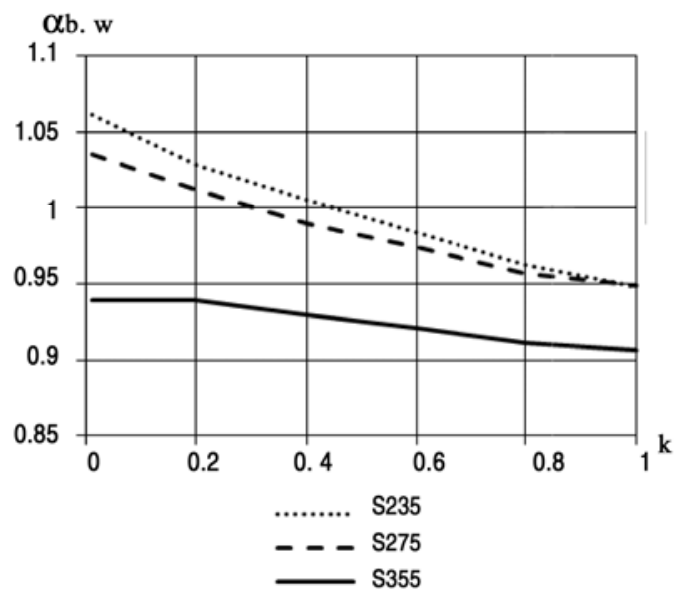

Fig. 8. Correction factor $\alpha_{b . w}$ depending on a second moment of area ratio. Relative slenderness of web -3.5

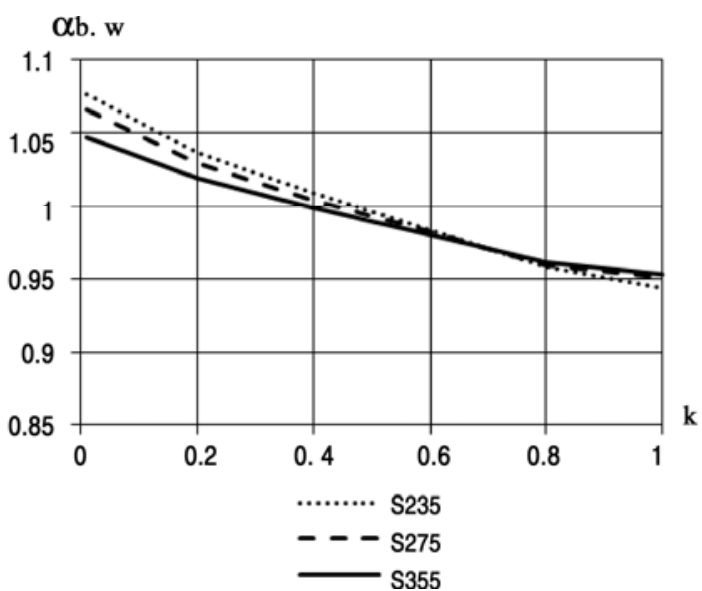

Fig. 9. Correction factor $\alpha_{b . w}$ depending on a second moment of area ratio. Relative slenderness of web -4.0

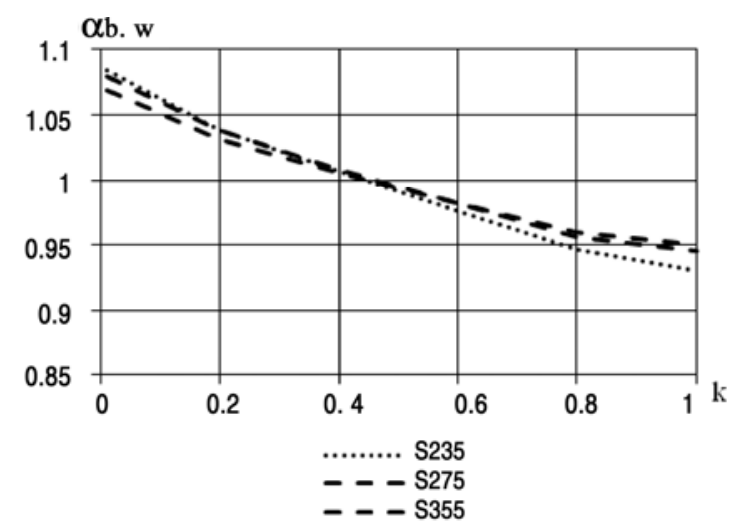

Fig. 10. Correction factor $\alpha_{b . w}$ depending on a second moment of area ratio. Relative slenderness of web -4.5

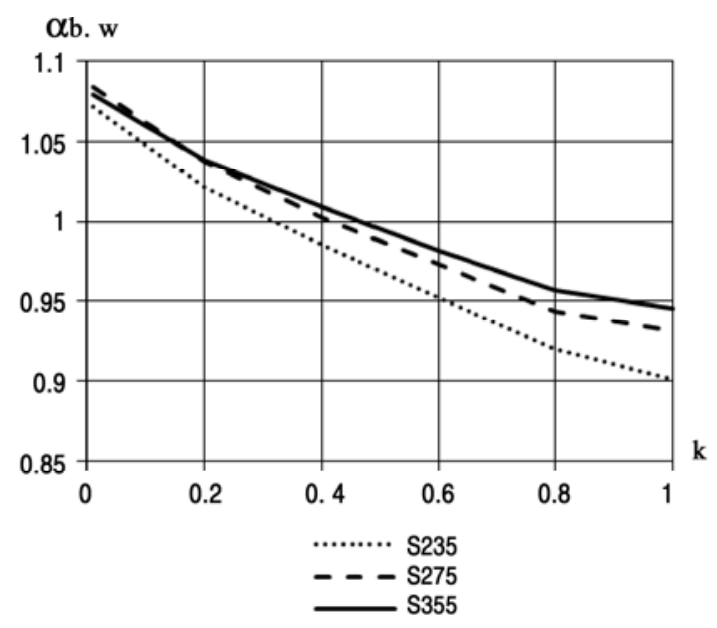

Fig. 11. Correction factor $\alpha_{b . w}$ depending on a second moment of area ratio. Relative slenderness of web -5.0 


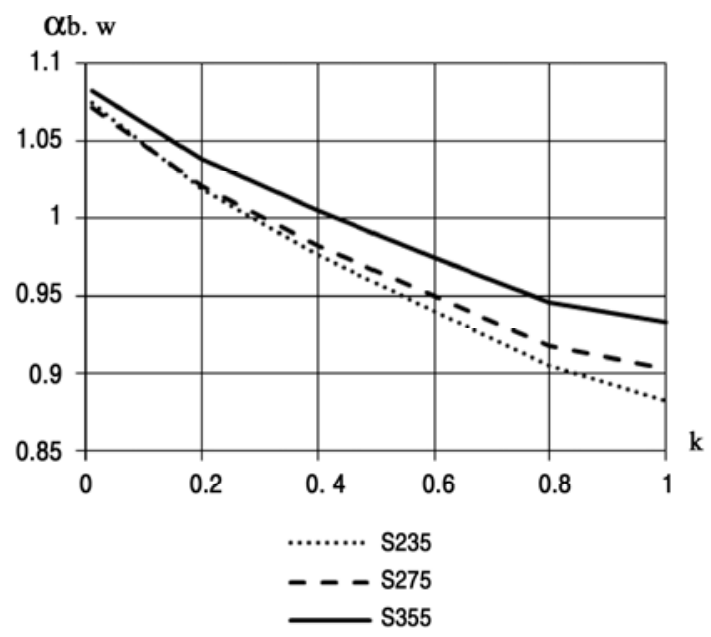

Fig. 12. Correction factor $\alpha_{b . w}$ depending on a second moment of area ratio. Relative slenderness of web -5.5

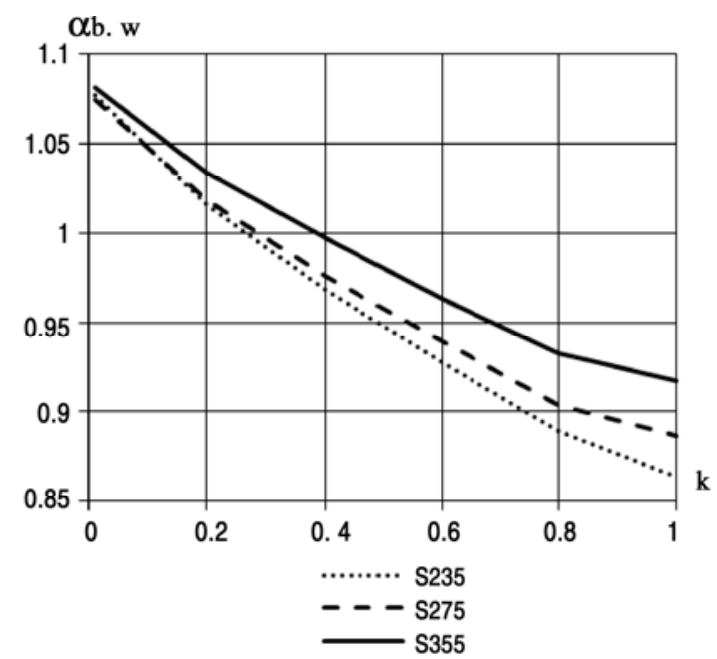

Fig. 13. Correction factor $\alpha_{b . w}$ depending on a second moment of area ratio. Relative slenderness of web -6.0

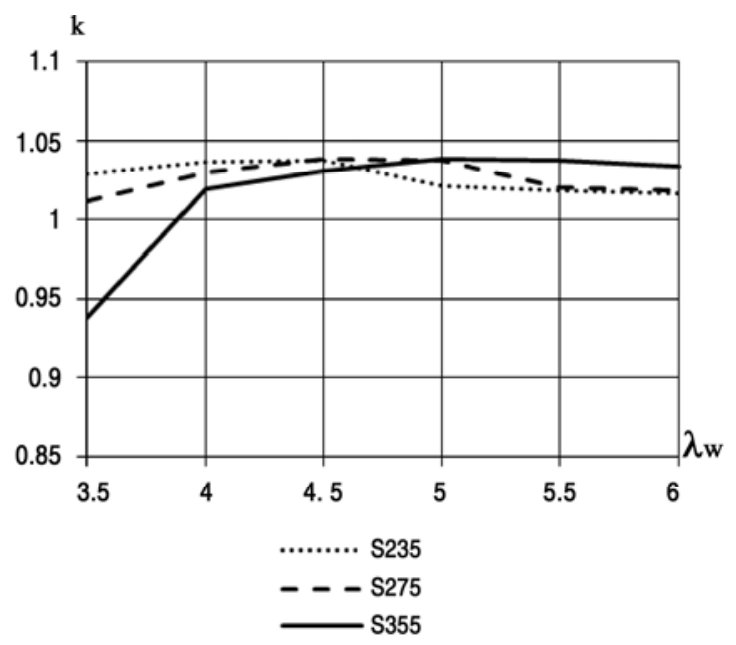

Fig. 14. Correction factor $\alpha_{b . w}$ depending on relative slenderness. Second moment of area ratio -0.2

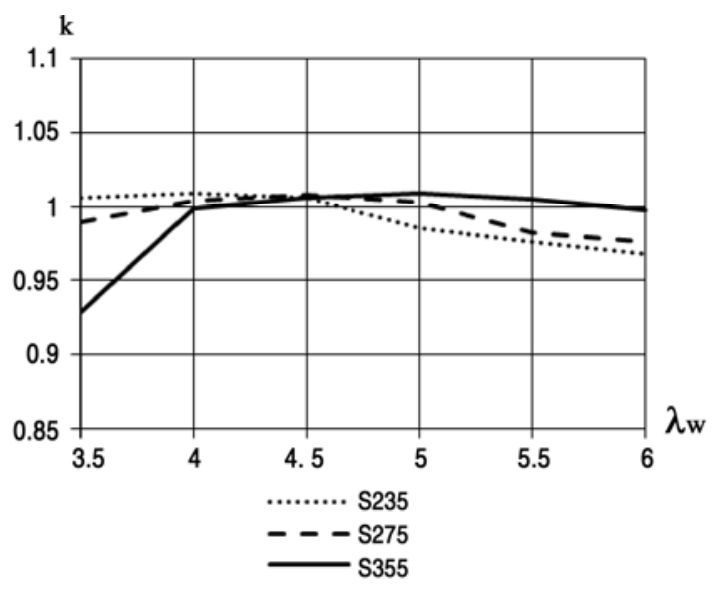

Fig. 15. Correction factor $\alpha_{b . w}$ depending on relative slenderness. Second moment of area ratio -0.4

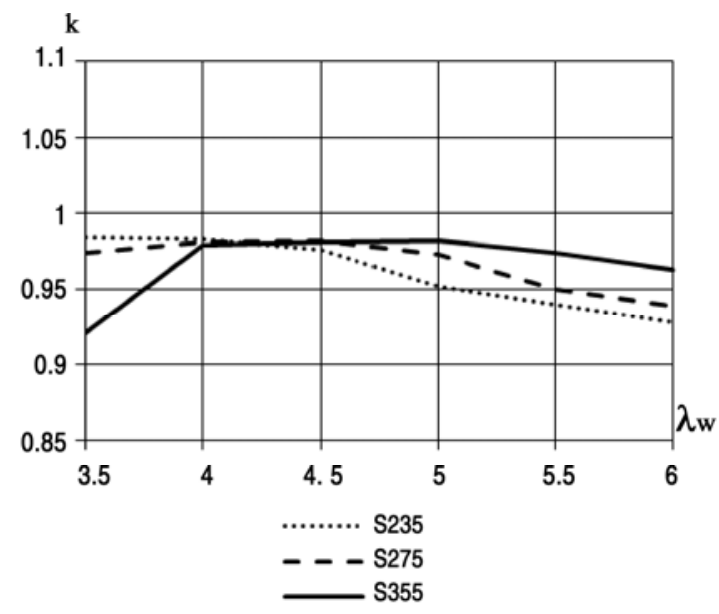

Fig. 16. Correction factor $\alpha_{b . w}$ depending on relative slenderness. Second moment of area ratio - 0.6

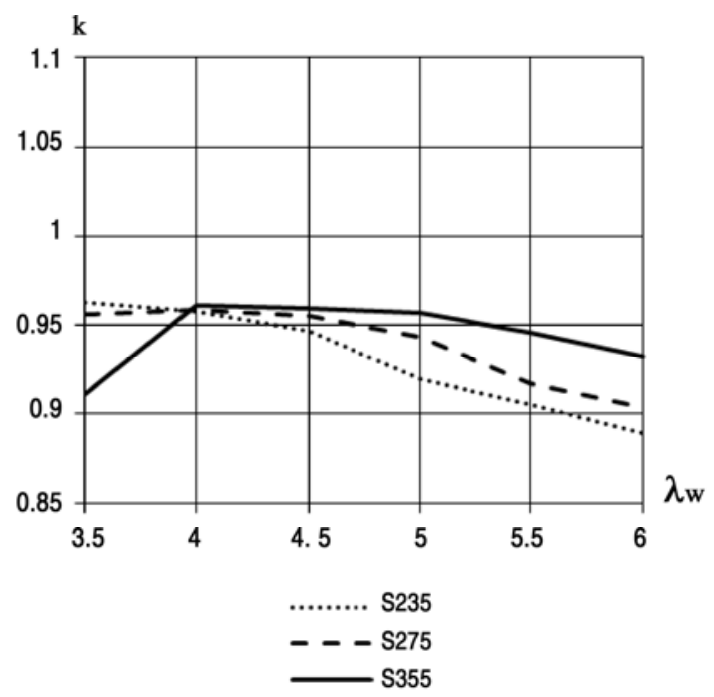

Fig. 17. Correction factor $\alpha_{b . w}$ depending on relative slenderness. Second moment of area ratio -0.8 


\section{Conclusions}

1. From the numerical experiments the correction factor for calculation local stability of the web of tapered beam subjected to pure bending was obtained.

2. After the analysis of the obtained results there was determined, that this factor depends only on the beams ends cross-section moments of inertia ratio.

3. When the relative slenderness is increasing the resistance of beam's web stability is also increasing.

4. When the second moment of area ratio is increasing from 0.05 to 1 , the resistance of beam's web stability is decreasing.

5. Local stability of the web of tapered beam is greater as compared to the uniform beam.

\section{References}

Andrade, A.; Camotim, D.; Dinis, P. B. 2007. Lateral-torsional buckling of singly symmetric web-tapered thin-walled I-beams: 1D model vs. shell FEA, Computers \& Structures 85(17-18): 1343-1359. doi:10.1016/j.compstruc.2006.08.079

Bazeos, N.; Karabalis, D. L. 2006. Efficient computation of buckling loads for plane steel frames with tapered members, Engineering Structures 28(5): 771-775. doi:10.1016/j.engstruct.2005.10.004

Becque, J.; Rasmussen, K. J. R. 2009. Experimental investigation of local-overall interaction buckling of stainless steel lipped channel columns, Journal of Constructional Steel Research 65(8-9): 1677-1684. doi:10.1016/j.jcsr.2009.04.025

Das, D.; Sahoo, P.; Saha, K. 2009. Out-of-plane free vibration analysis of rotating tapered beams in post-elastic regime, Materials \& Design 30(8): 2875-2894.

Eurocode 3. Design of Steel Structures. Part 1.1: General Rules and Rules for Buildings. 2006. 91 p.

Yau, J.-D. 2006. Stability of tapered I-Beams under torsional moments, Finite Elements in Analysis and Design 42(10): 914-927. doi:10.1016/j.finel.2006.01.008

Li, G.-Q.; Li, J.-J. 2002. A tapered Timoshenko-Euler beam element for analysis of steel portal frames, Journal of Constructional Steel Research 58: 1531-1544. doi:10.1016/S0143-974X(02)00003-2

Moon, J.; Yi, J.; Choi, B. H.; Lee, H.-E. 2009. Shear strength and design of trapezoidally corrugated steel webs, Journal of Constructional Steel Research 65(5): 1198-1205. doi:10.1016/j.jcsr.2008.07.018

Ozgumus, O. O.; Kaya, M. O. 2007. Energy expressions and free vibration analysis of a rotating double tapered Timoshenko beam featuring bending-torsion coupling, International Journal of Engineering Science 45(2-8): 562-586.
Raftoyiannis, I. G.; Ermopoulos, J. Ch. 2005. Stability of tapered and stepped steel columns with initial imperfections, Engineering Structures 27(8): 1248-1257. doi:10.1016/j.engstruct.2005.03.009

Ronagha, H. R.; Bradfordb, M. A.; Attardb, M. M. 2000. Nonlinear analysis of thin-walled members of variable crosssection. Part II: Application, Computers \& Structures 77: 301-313. doi:10.1016/S0045-7949(99)00224-2

Saffari, H.; Rahgozar, R.; Jahanshahi, R. 2008. An efficient method for computation of effective length factor of columns in a steel gabled frame with tapered members, Journal of Constructional Steel Research 64(4): 400-406. doi:10.1016/j.jcsr.2007.09.001

Salem, A. H.; El Aghoury, M.; Fayed, M. N.; El Aghoury, I. M. 2009. Ultimate capacity of axially loaded thin-walled tapered columns with doubly symmetric sections, Thin-Walled Structures 47(9): 931-941. doi:10.1016/j.tws.2009.02.011

Samofalov, M.; Kutas, R.; Kačianauskas, R. 2004. Computational tools for semi-analytical finite element stability analysis of thin-walled structures, Information Technology and Control 1(30): 32-43.

Šapalas, V.; Kvedaras, A. 2002. Critical bending moment of tapred members subjected to pure bending, Journal of Civil Engineering and Management 8(1): 52-56.

Šapalas, V.; Samofalov, M.; Šaraškinas, V. 2004. FEM analysis of stability problem of tapered beam-columns, in Proc of the 8th International Conference "Modern Building Materials, Structures and Techniques”, Vilnius, Lithuania, 2004. Vilnius: Technika, 620-626.

Šapalas, V.; Samofalov, M.; Šaraškinas, V. 2005. FEM stability analysis of tapered beam-columns, Journal of Civil Engineering and Management 8(1): 52-56.

Šapalas, V. 2000. Trapecinių kolonų vienanaviuose rėmuose deformacijų-itempiu būvis [Stress-strain analysis of single span frames with tapered members], Statyba [Journal of Civil Engineering and Management] 6(2): 82-86.

Šapalas, V.; Kvedaras, A. K. 2000. Centriškai gniuždomų kolonų stabilumas [Stability of axially loaded tapered columns], Statyba [Journal of Civil Engineering and Management] 6(3): 158-161.

Šešok, D.; Belevičius, R. 2008. Global optimization of trusses with a modified genetic algorithm, Journal of Civil Engineering and Management 14(3): 147-154. doi:10.3846/1392-3730.2008.14.10

Zhang, L.; Tong, G. S. 2008. Lateral buckling of web-tapered I-beams: A new theory, Journal of Constructional Steel Research 64(2): 1379-1393. doi:10.1016/j.tws.2009.02.011

Динник, А. Н. 1955. Продольный изгиб. Кручение [Dinnik, A. N. Buckling. Torsion]. Москва: АН СССР, 1955. 451 c.

\section{GRYNAI LENKIAMOS TRAPECINĖS SIJOS SIENELE்S VIETINIS PASTOVUMAS \\ V. Šapalas}

S a n tra u k a

Straipsnyje aprašyti teoriniai ir skaitmeniniai grynai lenkiamų trapecinių sijų sienelès vietinio pastovumo tyrimai. Kritinis apkrovos daugiklis gautas baigtinių elementų metodo programa COSMOS/M. Atlikus teorinius tyrimus nustatyta, kad trapecinès sijos sienelès vietini pastovumą galima apskaičiuoti kaip pastovaus skerspjūvio sijai naudojant papildomą koeficientą $\alpha_{b . w}$. Atlikus skaitinius eksperimentus kintant sijos galų skerspjūvio inercijos momentų santykiui, gautos tikslios šio koeficiento reikšmės. Straipsnyje nagrinèta plieno klasės, sijos sienelės sąlyginio liaunio ir sijos galų skerspjūvio inercijos momentų santykio įtaka grynai lenkiamai trapecinei sijai.

Reikšminiai žodžiai: vietinis sienelès pastovumas, grynai lenkiama trapecinė sija, baigtinių elementų metodas, kritiniai sienelès ittempiai.

Vaidotas ŠAPALAS. Dr. Assoc. Professor of Steel and Timber Department. Vilnius Gediminas Technical University. Lithuania. Research interests: tapered elements, FE method, local stability, lateral-torsional stability. 